\title{
Can halal be sustainable? Study on Malaysian consumers perspective
}

\begin{abstract}
Halal provides guidelines for food production, processing, and handling. Thus, the extent of which segments of Halal food preparation (food safety, environmentally friendly, animal welfare, and fair trade) influence consumers' perception toward sustainable agriculture development is being studied. Using an ordered probit model, factors that significantly influence the sustainability concept arising from practicing Halal principles are determined. The majority of consumers reported that Halal food production can be an effective vehicle to promote sustainable farming and agriculture. Food safety, environmentally friendly, fair trade, and animal welfare are the most likely determinants associated with Halal principles and production to support sustainable agriculture.
\end{abstract}

Keyword: Halal principles; Sustainable agriculture; Consumer perception ordered 